\title{
Motivation, Competence, Workload, and Their Association with Nurse Performance in Dr. Arif Zaenudin Hospital, Surakarta
}

\author{
Tia Martha Pundati'), Didik Tamtomo²), Endang Sutisna Sulaeman²) \\ ${ }^{1)}$ Masters Program in Public Health, Universitas Sebelas Maret \\ ${ }^{2)}$ Faculty of Medicine, Universitas Sebelas Maret
}

\begin{abstract}
Background: Nurses performance remains long standing determinates of quality service rendered for patients admitted to hospitals. Improvements in quality health service can be achieved by improving nurse performance. This study aimed to analyze the relationship of competence, motivation, and workload on the nurse performance in Surakarta.

Subjects and Method: This was a cross sectional study conducted at Dr. Arif Zaenudin Mental Hospital, Surakarta, Central Java, from November 24 to December 24, 2017. A sample of 200 study subjects was selected by total sampling. The dependent variable is the nurse's performance, while the independent variables are competence, motivation, workload, employment status, education and the distance between the nurse's residence and the hospital. The dependent and independent variables were measured using a questionnaire. The data analysis was done using path analysis with the STATA 13 program.

Results: The performance is influenced by competence $(b=1.08 ; 95 \% \mathrm{CI}=0.32$ to $1.74 ; \mathrm{p}=0.005)$, motivation $(b=0.91 ; 95 \% \mathrm{CI}=0.15$ to $1.68 ; \mathrm{p}=0.019)$, workload $(\mathrm{b}=2.65 ; 95 \% \mathrm{CI}=1.91$ to 3.40 , $\mathrm{p}<0.001$ ), there are 2 variables that have an indirect relationship with the nurse's performance, namely education $(\mathrm{b}=0.67 ; 95 \% \mathrm{CI}=-1.24$ to $-0.11 ; \mathrm{p}=0.019)$ and the distance of residence $(\mathrm{b}=-$ $0.61 ; 95 \% \mathrm{CI}=-1.20$ to $-0.20 ; \mathrm{p}=0.043)$.

Conclusion: There is a direct relationship between competence, motivation, workload and work period with nurse performance. There is an indirect relationship between education and home distance with performance.
\end{abstract}

Keywords: pathway analysis, competence, motivation, workload, performance

\section{Correspondence:}

Tia Martha Pundati. Masters Program in Public Health, Universitas Sebelas Maret, Jl. Ir. Sutami 36 A, Surakarta 57126, Central Java. Email: tiamarthapundati@gmail.com

\section{BACKGROUND}

Hospital (RS) is one form of health service strata in the National Health System (SKN) which is also a medical referral pathway in health efforts as well as being the highest hierarchy of recovery and recovery efforts for patients who are complex and dynamic, labor intensive, capital intensive and is influenced by the ever-changing internal and external environment (MOH, 2006). Hospitals are currently in a global and competitive atmosphere, including competing with alternative services so that their services should be managed on the basis of ethical management concepts. Management of health human resources (HR) in hospitals as a demand to be able to compete with other hospitals. Improving the quality of human resources is very important to deal with competition in health services in the era of technological progress (Trisnantoro, 2009).

Factors that support the achievement of good health services are the availability of health personel for 24 hours to treat patients. One health personnel who plays a role in providing services for 24 hours is nursing staff (Hiryani, 2010). Health 
services in hospitals, especially in the field of nursing, their duties and functions must be based on awareness of tasks and high responsibilities so that the task of health services for the community can be managed properly and satisfactorily in accordance with patient expectations.

Nursing as a form of professional service is an integral part that is inseparable from the overall health care. This is emphasized in the Republic of Indonesia Law No.36 of 2009 concerning Health. In addition, the health services provided by nursing staff are also regulated in the Regulation of the Minister of Health of the Republic of Indonesia Number 10 of 2015 concerning Nursing Service Standards in Special Hospitals. The application of nursing care standards is one of the efforts to achieve maximum health in carrying out its activities (Keliat, 2009).

Mental Hospital (RSJ) is one of the government work tools which is also one of the health efforts that need attention. The number of people with mental disorders in the province of Central Java is fifth in Indonesia. Meanwhile, the Regional Mental Hospital (RSJD) Dr. Arif Zaenudin Surakarta experienced an increase in the number of patients each year. According to Dr. Arif Zaenudin's 2017 profile data on the RSJD, nurses at the Dr Arif Zaenudin Hospital were 252 nurses who had different levels of education. The level of undergraduate nursing/ NERS is about $65.4 \%$ (165 nurses) and Diploma III levels about $34.6 \%$ (87 nurses). Inpatient Installation at Surakarta Hospital consists of 340 beds divided into 16 treatment rooms. According to Lintang (2011), the ratio of normal nurses is 1: 5 , which means that every nurse handles 1-5 patients. While the ratio of nurses at the Dr Arif Zaenudin Hospital in 2016 is 1:11.
Nurses are the spearhead of the services provided at the hospital. This is because this profession is directly related to patients. If the quality of services provided by nurses is good then the satisfaction of patients will increase (Kristami, 2008). Based on medical records of RSJD Dr. Arif Zaenudin, the number of outpatients in 2012 was 20,559 patients, in 2013 it increased to 21,111 patients and in 2014 it increased to 22,132 patients. Meanwhile, the number of inpatients in 2014 was 3,037 patients experienced a decline in 2015 to 2,875 patients. However, in 2016, it experienced a return to 2,905 patients. The increase in the number of patients each year must be balanced with the good performance of nurses in accordance with the vision and mission of the RSJD Dr. Zaenudin namely "Becoming a professional and cultured mental health service center". The quality of the nursing profession's performance will be maximal and focus on professionalism when the nurse's competence, motivation and workload are in accordance with its main tasks and functions.

One indicator that determines the performance of nurses in hospitals is BOR (Bed Occupancy Rate) and LOS (Length of Stay). The performance indicator of BOR (Bed Occupancy Rate) in the Hospital of Arif Zaenudin Surakarta in 2016 reached $75.49 \%$ above the target set of $70 \%$. Meanwhile, for the achievement of the performance of increasing mental health service quality as measured by the LOS indicator (Length of Stay), the realization was 32 days. This is not according to the set target of 28 days. Low BOR figures indicate the lack of use of hospital care facilities by patients. A high BOR rate ( $>85 \%)$ indicates a high level of bed utilization so that hospital development and additional beds are needed. ALOS (Average Length of Stay) 
is the average length of stay. A high LOS rate ( $>12$ days) indicates a level of inefficiency in a hospital service.

The results of the preliminary study through observation and interviews with service satisfaction were conducted on August 7, 2017 at Dr. RSD. Arif Zaenudin, all the wards at Dr. RSD Arif Zaenudin Surakarta amounted to 16 wards have implemented nursing care to provide good health services for patients. From the results of the interviews, the hospital said that nursing care had been carried out but it was still less than optimal considering the large number of patients increasing every year. RSJD officer, Dr. Arif Zaenudin stated that the large number of patients that increased caused a high nurse workload. Apart from the hospital, the researchers conducted interviews with three families whose family members had been hospitalized at the Dr Arif Zaenudin Hospital. Of the three families of the patients stated that the service still needs to be improved because there are still nurses who are not friendly.

From this background, the researcher wanted to analyze the relationship between motivation, competence, and workload on the performance of nurses in implementing nursing care in the inpatient unit of the RSJD Dr Arif Zaenudin, Surakarta.

\section{SUBJECT AND METHOD \\ 1. Study Design \\ This a case control study conducted at Dr. Arif Zaenudin Mental Hospital, Surakarta, from September to November 2018.}

\section{Population and Samples}

The target population of the study were nurses at the Mental Hospital. While the source population (affordable population) in this study were nurses in the inpatient installation of the RSJD Dr. Arif Zaenudin, Surakarta. The sample of 200 nurses who were hospitalized was chosen by total sampling.

\section{Study Varibles}

The dependent variable is the nurse's performance. The independent variables are motivation, competence, and workload.

4. Operational Definition of Variables Competence was defined as physical intellectual ability and human relationships that underlie nurses in applying nursing care. The data were collected using questionnaires. The measurement scale was continous, but for analysis purpose it was transformed into dichotomy, coded o for less and 1 for good.

Motivation was defined as an impulse that arises from the nurse's assessment of the RSJD organization Dr. Arif Zaenudin. The data were collected using questionnaires. The measurement scale is continous, but for analysis purposes the data are changed to dichotomy, code o for less and 1 for good.

Workload was defined as a work condition that is adjusted to the main tasks and functions that the nurse must complete. Measuring tool was a questionnaire. The data were collected using questionnaires. The measurement scale was continous, but for analysis purposes the data are changed to a dichotomy, code o for weight and 1 for light.

Performance is defined as the access or distance from home to the health service to carry out pap smears. The data were collected using questionnaires. The measurement scale is continuous, but for analysis purposes the data are changed to dichotomy, code o for less and 1 for good.

\section{Data Collection}

The research instrument that was used for data collection in this study is a questionnaire.

The validity test of the questionnaire was carried out on 20 nurses at the Dr. Arif 
Journal of Health Policy and Management (2018), 3(2): 63-70

https://doi.org/10.26911/thejhpm.2018.03.02.01

Zaenudin Hospital. The validity used is content validity. Question items with an item-total correlation coefficient of less than 0.20 are discarded and if necessary, they were rewritten. The face validity was consulted with Prof. Dr. Didik Gunawan Tamtomo, Dr., MM, MKes, PAK and Dr. Endang Sutisna Dr., MKes, FISPH, FISCM as research advisor.

The reliability testing in this study was carried out on 20 nurses at the RSJD Dr Arif Zaenudin. Reliability tests were performed to calculate item-total correlations and Cronbach alpha.

\section{Data Analysis}

Characteristics, motivation, competence, workload and nurse performance are described in $\mathrm{n}$ and\%. Bivariate analysis was conducted using chi-square test with $\mathrm{CI}$ and significance level $\mathrm{p}<0.05$. The relationship of the variables under study is then analyzed using the path analysis model. Path analysis is used to test the validity of a theory that describes a causal relationship between three or more variables as a continuation of a correlation study (Ali, 2014).

Table 2. The Results of Bivariate Analysis of Motivation, Competence, Workload, and Nurse Performance

\begin{tabular}{|c|c|c|c|c|c|c|c|}
\hline \multirow[b]{2}{*}{ Variable } & \multirow[b]{2}{*}{ Category } & \multicolumn{2}{|c|}{ Nurse Performance } & \multirow[b]{2}{*}{$\mathbf{O R}$} & \multicolumn{2}{|c|}{$95 \%$ CI } & \multirow[b]{2}{*}{$\mathbf{p}$} \\
\hline & & Poor & Good & & $\begin{array}{c}\text { Lower } \\
\text { Limit }\end{array}$ & $\begin{array}{l}\text { Upper } \\
\text { Limit }\end{array}$ & \\
\hline \multirow[t]{2}{*}{ Education } & Graduate & $36(34.6 \%)$ & $68(65.4 \%)$ & \multirow[t]{2}{*}{0.55} & \multirow[t]{2}{*}{0.31} & \multirow[t]{2}{*}{0.98} & \multirow[t]{2}{*}{$<0.040$} \\
\hline & Diplo & $47(49.0 \%)$ & $49(5$ & & & & \\
\hline \multirow{2}{*}{$\begin{array}{l}\text { The Distance } \\
\text { from Hospital } \\
\text { to Residence }\end{array}$} & $<5 \mathrm{~km}$ & $42(31.8 \%)$ & $90(68.2 \%)$ & \multirow[t]{2}{*}{0.31} & \multirow[t]{2}{*}{0.17} & \multirow[t]{2}{*}{0.57} & \multirow[t]{2}{*}{$<0.001$} \\
\hline & $\geq 5 \mathrm{~km}$ & $41(60.3 \%)$ & $27(39.7 \%)$ & & & & \\
\hline \multirow[t]{2}{*}{ Motivation } & Low & $48(57.1 \%)$ & $36(42.9 \%)$ & \multirow[t]{2}{*}{3.09} & \multirow[t]{2}{*}{1.72} & \multirow[t]{2}{*}{5.55} & \multirow[t]{2}{*}{$<0.001$} \\
\hline & High & $35(30.2 \%)$ & $81(6$ & & & & \\
\hline \multirow[t]{2}{*}{ Competence } & Poor & $56(61.5 \%)$ & $35(38.5 \%)$ & \multirow[t]{2}{*}{4.86} & \multirow[t]{2}{*}{2.65} & \multirow[t]{2}{*}{8.91} & \multirow[t]{2}{*}{$<0.001$} \\
\hline & Good & $27(24.8 \%)$ & $82(75.2 \%)$ & & & & \\
\hline \multirow[t]{2}{*}{ Workload } & Heavy & $65(75.6 \%)$ & $21(24.4 \%)$ & \multirow[t]{2}{*}{16.51} & \multirow[t]{2}{*}{8.17} & \multirow[t]{2}{*}{33.37} & \multirow[t]{2}{*}{$<0.001$} \\
\hline & Easy & $18(15.8 \%)$ & $96(84.2 \%)$ & & & & \\
\hline
\end{tabular}

Table 2 presented a bivariate analysis between motivation, competence, and workload on nurse performance. Low education

\section{Research Ethics}

The research ethics include informed consent, anonimity, and confidentiality.

\section{RESULTS}

Table 1. The Descriptions of Research Variable

\begin{tabular}{|c|c|c|}
\hline Variable & $\mathbf{n}$ & $\%$ \\
\hline \multicolumn{3}{|l|}{ Education } \\
\hline Professional Bachelor/ & 104 & 52 \\
\hline S.Kep / Ners & 96 & 48 \\
\hline \multicolumn{3}{|l|}{ SKP / Diploma } \\
\hline \multicolumn{3}{|l|}{ The Distance from } \\
\hline Hospital to Residence & 132 & 66 \\
\hline$<5 \mathrm{~km}$ & 68 & 54 \\
\hline$\geq 5 \mathrm{~km}$ & & \\
\hline \multicolumn{3}{|l|}{ Motivation } \\
\hline Less Motivation & 84 & 42 \\
\hline Good Motivation & 116 & 58 \\
\hline \multicolumn{3}{|l|}{ Competence } \\
\hline Less Competence & 91 & 45.5 \\
\hline Good Competence & 109 & 54.5 \\
\hline \multicolumn{3}{|l|}{ Workload } \\
\hline Heavy Workload & 86 & 43 \\
\hline Easy Workload & 114 & 57 \\
\hline \multicolumn{3}{|l|}{ Performance } \\
\hline Lack of Performance & 83 & 41.5 \\
\hline Good Performance & 117 & 58.5 \\
\hline
\end{tabular}

decreased nurse performance $(\mathrm{OR}=0.55$; 95\% CI $=0.31$ to $0.98 ; \mathrm{p}=0.040$ ). Longer distance from residence to hospital 
decreased nurse performance $(\mathrm{OR}=0.31$; motivation increased nurse performance $95 \% \mathrm{CI}=0.17$ to $0.57 ; \mathrm{p}<0.001)$. Strong $\quad(\mathrm{OR}=3.09 ; 95 \% \mathrm{CI}=1.72$ to $5.55 ; \mathrm{p}<0.001)$.

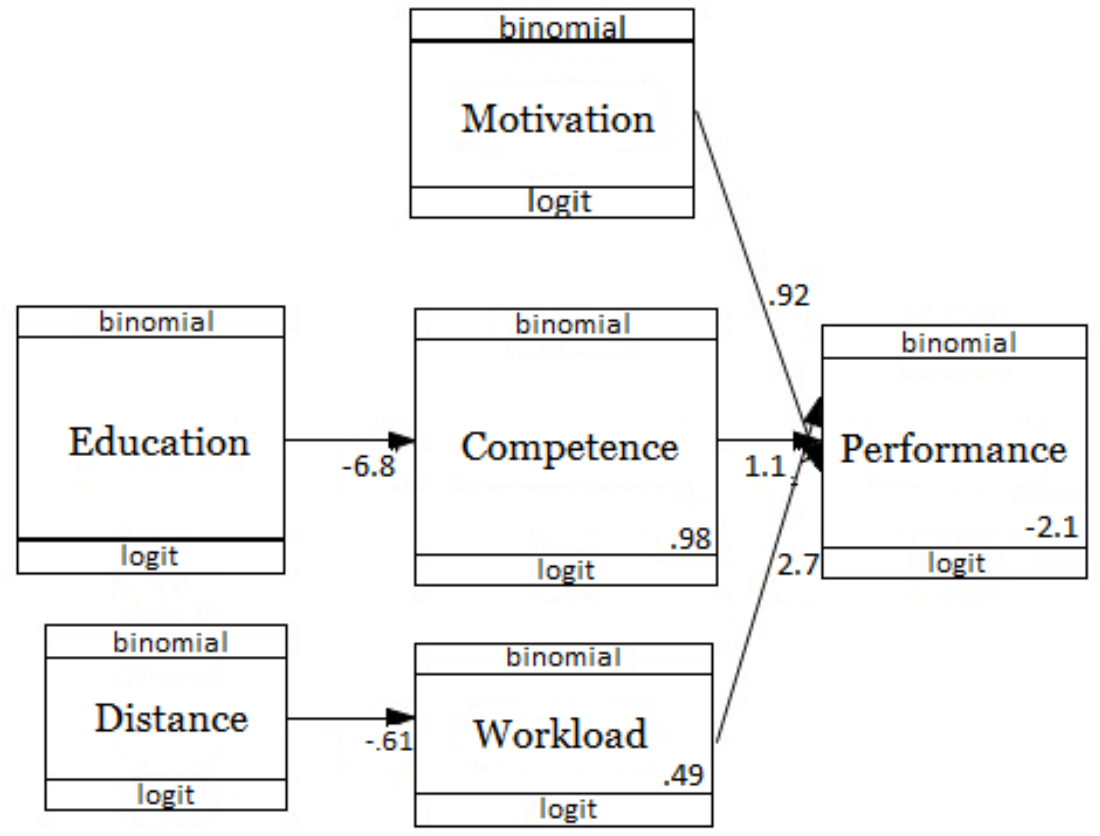

Figure 1. Path Analysis Model Specifications

In the competence and nurse performance variables, the score of Odds ratio (OR) chisquare was 4.86 and the score of $\mathrm{p}<0.001$; CI $(95 \%)=2.65$ to 8.91 . There was a strong and positive relationship between work competence and nurse performance. In the workload and nurse performance variables, the score of Odds ratio (OR) chi-square was $(\mathrm{OR}=16.51 ; 95 \% \quad \mathrm{CI}=8.17$ to 33.37 ; $\mathrm{p}<0.001)$. This showed that there was a strong, significant, and positive relationship between workload and nurse performance.

Table 3. The Results of Path Analysis on the Determinants of Nurse Performance

\begin{tabular}{|c|c|c|c|c|c|c|c|}
\hline \multirow{2}{*}{\multicolumn{2}{|c|}{$\begin{array}{l}\text { Dependent } \\
\text { Variable }\end{array}$}} & \multirow[b]{2}{*}{$\begin{array}{l}\text { Independe } \\
\text { nt Variable }\end{array}$} & \multirow[b]{2}{*}{ b } & \multirow[b]{2}{*}{ SE } & \multicolumn{2}{|c|}{$95 \% \mathrm{CI}$} & \multirow[b]{2}{*}{$\mathbf{P}$} \\
\hline & & & & & $\begin{array}{c}\text { Lower } \\
\text { Limit }\end{array}$ & $\begin{array}{c}\text { Upper } \\
\text { Limit }\end{array}$ & \\
\hline \multicolumn{8}{|l|}{ Direct Relationship } \\
\hline Nurse Performance & $\leftarrow$ & Competence & 1.08 & 0.38 & 0.32 & 1.83 & 0.005 \\
\hline Nurse Performance & $\leftarrow$ & Motivation & 0.91 & 0.39 & 0.15 & 1.68 & 0.019 \\
\hline Nurse Performance & $\leftarrow$ & Workload & 2.65 & 0.38 & 1.91 & 3.40 & $<0.001$ \\
\hline \multicolumn{8}{|l|}{ Indirect Relationship } \\
\hline Competence & $\leftarrow$ & Education & 0.67 & 0.28 & -1.24 & 0.11 & 0.019 \\
\hline $\begin{array}{l}\text { Workload } \\
\text { N Observation = 200 } \\
\text { Log likehood }=-358.38\end{array}$ & $\leftarrow$ & Distance & -0.61 & 0.30 & -1.20 & -0.02 & 0.043 \\
\hline
\end{tabular}

Table 3 indicated that the results of calculations by using STATA 13 computer program software showed that there was a direct and indirect relationship between motivation, competence, and workload on nurse performance.
Nurse performance was directly associated with competence, motivation, and workload. Nurse performance increased with good competence $(b=1.08$; 95\% CI= 0.32 to $1.83 ; \mathrm{p}=0.005$ ), strong motivation $(b=0.91 ; 95 \% \mathrm{CI}=0.15$ to $1.68 ; \mathrm{p}=0.019)$, 
and low workload $(2.65 ; 95 \% \mathrm{CI}=1.91$ to $3.40 ; \mathrm{p}<0.001)$.

\section{DISCUSSIONS}

\section{The Relationship between Motiva-} tion and Nurse Performance

The result of this study showed that there was a positive relationship between motivation and nurse performance. The relationship was positive and significant. The result of this study showed that the better the nurse's motivation, the better the nurse's performance in applying nursing care. Nurse motivation at Dr. Arif Zaenudin Psychiatric Hospital was good and was considered capable of performing nursing care properly, so that the nurses were able to provide good services to the patients. These services include assessment, diagnosis, planning, implementation, evaluation, and documentationi.

The results of this study was consistent with a study done by Jimat (2013), which stated that motivation was closely related to the nurse performance in Bangli Hospital. Motivated individual would have the courage to do the task and assume that the task was interesting, challenging, fun, and even a necessity.

Therefore, it can be concluded that if the nurses have good motivation in doing their work, it would affect good performance in implementing nursing care. Hee (2016) stated that motivation was important in improving the nurse work performance at the Malaysian Tourism Hospital. Therefore, hospital management must achieve a balance between intrinsic rewards and extrinsic rewards to increase nurse motivation so that nurse performance can be continuously improved.

\section{The Relationship between Compe- tence and Nurse Performance}

The result of this study showed that there was a positive relationship between compe- tence and nurse performance. This was in line with a study done by Langingi (2015) which stated that competence was related to the nurse performance in the inpatient installation of Prof. Dr. R.D. Kandou Hospital in Manado. Nurses' competencies were very important in improving nurses' performances. Competence reflected the ability of nurses to collaborate and interact with others in working to achieve personal and organizational goals.

A study by Amildawati (2015) mentioned that there was a relationship between competence and performance. Competence is the ability to do or to perform a job or task based on skills and knowledge which supported by the work attitude which demanded by the work itself. Performance has a causal relationship with competence, a superior implementer was a person who showed competence at a higher level scale with better results.

\section{The Relationship between Work- load and Nurse Performance}

The result of this study showed that there was a significant relationship between workload and nurse performance. This result was in line with a study done by Yulianto (2012) which stated that there was a significant relationship between workload and nurse performance. Nurses who have easy workloads have good performance in providing health services.

Excessive workload would cause various effects, namely physical and mental fatigue and emotional reactions such as headaches, indigestion, neglect, forgetfulness, and irritability. Therefore, it can potentially endanger the workers or nurses (Manuaba, 2000, in Prihatini, 2007).

\section{The Relationship between Educa- tion and Nurse Performance}

The result of this study showed that there was a relationship between education and nurse performance. The result of this study 
was in line with a study done by Hasanah (2015) which stated that there was a relationship between education and nurse performance in health services at Muntilan Hospital, Magelang District. This statement was supported by Bernardin (2007) who stated that education and training was an effort to develop staff performance in working or related to their work.

In this study, education was not directly related to nurse performance, but it was through competency variables. This was in line with a study done by Elysabeth (2012), which stated that there was a significant relationship between education and nurse competence at Siloam Hospitals, Kebon Jeruk. High level of education would generally cause a person to be more able and willing to accept their positions and responsibilities. According to Eizenberg (2010), this showed that education was able to guide someone to have good skill in finding sources of research, organizing, and being professional in work.

\section{The Relationship between the Distance from Residence to Hospital and Nurse Performance}

The result of this study showed that there was a relationship between the distance from residence to the Hospital and nurse performance. This study was in line with a study done by Solikha (2012) which stated that there was a relationship between workload and nurse performance. The workload was affected by the distance of the nurse residence to the workplace. Therefore, the nurses were tired and they cannot provide good performance. The study also showed that the distance of residence to work place was indirectly associated with nurses' performance.

Based on the results of this study, it can be concluded that there was a direct and significant relationship between motivation, competence, and workload with the nurse performances in implementing nursing care. There was an indirect relationship between education and the distance of residence to Hospital with the nurse performances in implementing nursing care.

\begin{tabular}{l}
\hline \multicolumn{3}{c}{ REFERENCE } \\
\hline Almidawati (2015). Analisis Kompetensi \\
dan Kinerja Kepala Ruangan dalam \\
Melaksanakan Fungsi Manajeman \\
Bangsal Menurut Perspektif Perawat \\
Pelaksana dan Faktor Determinannya \\
di Irna Ambun Pagi RSUP Dr. M. \\
Djamil Padang. Tesis. Universitas \\
Andalas.
\end{tabular}

Beinadin J (2007). Human Managemant: An Experiental Approach. The Mc Graw Companies. Boston.

Depkes RI (2011). Profil Kesehatan Indonesia Tahun 2011. Depkes RI. Jakarta.

Eizenberg M (2010). Implementation of Evidence Based Nursing Practice: Nurse's Personal and Professional Factors. Department of Health System Management Yezreel Valley College. Israel

Elysabeth D, Libranty G, Natalia S (2012). Correlation between Nurse's Education with The Competency To Do Evidence Based Practice. www.researchgate.com diakses Juli 2018.

Hasanah L, Koeswandari R (2015). Training and Nurse's Performance in Healthcare RSUD Muntilan Regency Magelang. Publication Article. Yogyakarta.

Hee OC, Kamaludin NH, Ping LL (2016). Motivation and Job Performance Among Nurse in The Health Tourism Hospital in Malaysia. International Review of Management and Marketing, 6(4).

Hiryani D (2010). Hubungan Motivasi dengan Kepuasan Kerja Sumber Daya 
Manusia Keperawatan di Rumah Sakit Siaga Raya Jakarta Selatan Tahun 2010. Fakultas Kesehatan Masyarakat Universitas Indonesia. Skripsi

Langingi ARC (2015). Hubungan Faktor Internal dan Eksternal dengan Kinerja Perawat Pelaksana di Instalasi Rawat Inap C RSUP Prof Dr. R. D. Kandou Manado. Tesis. Universitas Sam Ratulangi

Keliat A (2009). Model Praktik Keperawatan Profesional Jiwa. Penerbit EGC. Jakarta

Kristami SD (2008). Pengaruh Faktorfaktor Motivasi Kerja terhadap Kinerja Perawat di RSUD Penembahan Senopati Bantul. Skripsi

Prihatini LD (2007). Analisis Hubungan Beban Kerja dengan Stres Kerja Perawat di Tiap Ruang Rawat Inap
RSUD Sidikalang. Tesis. Universitas Sumatera Utara. Medan

Ragab SA, Altorky MAM, Ghallab SA (2017). Relationship between Performance Obstacles and Workload Among Intersive Care Nurses at Assiut University Hospital. The Malaysian Journal of Nursing. 9 (2).

Trisnantoro L (2009). Manajemen Rumah Sakit. Penerbit BPEE Yogyakarta. Yogyakarta.

Yulianto (2012). Hubungan antara Beban Kerja Perawat dengan Kinerja Perawat dalam Memberikan Asuhan Keperawatan. Jurnal Keperawatan dan Kebidanan STIKES Dian Husada Mojokerto 